\title{
Monitoring of the employee's Internet use in the workplace in the light of selected case law of the European Court of Human Rights and Polish case law
}

\author{
Karolina Mania, Jagiellonian University \\ ORCID ID: 0000-0001-9063-7563
}

\begin{abstract}
Streszczenie:
Artykuł stanowi analize wybranego orzecznictwa Europejskiego Trybunału Praw Człowieka (ETPC) i orzecznictwa polskiego w zakresie monitoringu wykorzystywania Internetu przez pracownika w miejscu pracy. Wybór przedmiotu badawczego został oparty na obserwacji Autorki w zakresie istnienia niuansów i rozbieżności orzecznictwa ETPC w badanym temacie, jak i rozpoznania rosnącej istotności zagadnienia w kontekście wzrastającego korzystania z sieci Internet przez pracowników w pracy. Badania przeprowadzono wykorzystując takie metody badawcze, jak: analiza treści, metoda prawno-porównawcza i metoda formalno-dogmatyczna.
\end{abstract}

Stowa kluczowe: Europejski Trybunał Praw Człowieka, wykorzystanie Internetu, monitoring, miejsce pracy, prawo Internetu

Monitoring wykorzystywania Internetu przez pracownika w miejscu pracy w świetle wybranego orzecznictwa Europejskiego Trybunatu Praw Człowieka i orzecznictwa polskiego

\begin{abstract}
:
This article analyses selected case law of the European Court of Human Rights (ECHR) as well as Polish case law in the subject matter specified in the title, i.e. the monitoring of Internet use by employees in the workplace. The author has selected the research subject based on the own observations on the existence of nuances and divergences in the ECHR's case law in this field, as well as a growing importance of this matter in the context of increasing employees' online activity at work. The study is based on such research methods as content analysis, comparative legal methodology and the formal-dogmatic approach.
\end{abstract}

Keywords: European Court of Human Rights, Internet use, monitoring, workplace, Internet law 
The current discussion on recognising Internet access as one of the fundamental human rights highlights the importance and legal significance of Internet use in many fields, including the professional one. Any Internet use restrictions introduced by domestic legislators or internal regulations raise controversies while the absence of consistent jurisprudence on the matter leads to legal uncertainty.

This article analyses the case law of the European Court of Human Rights (ECHR) concerning the monitoring of employees' Internet use at work, with special emphasis on the widely commented judgment of the Grand Chamber of the European Court of Human Rights of 5 September 2017 in Case of Bărbulescu v. Romania (hereinafter ECHR 2017), where the Court stated that a disciplinary dismissal of an employee, who had been using company resources (hardware, Internet access) for private purposes, constituted a breach of the right to respect for the employee's private and family life, as well as his/her right of correspondence. A discussion of the matter in question from the perspective of national legislation and selected Polish case law will be presented in the last section of the article.

\section{Research Methodology}

The author has analysed the case law of the European Court of Human Rights and, on the basis of the selected methodology, has written this article being a comprehensive source of understanding of the ECHR's position concerning the monitoring of employees' Internet use in the workplace with reference to legislation in force, as well as selected Polish case law.

The research objectives have determined the selection of research methods including content analysis, comparative legal methodology and the formal-dogmatic approach. An in-depth analysis of literature has made it easier to learn about the key literature sources and epistemological foundations of the subject matter discussed here. This, in turn, has facilitated the formulation of a specific problem, compiling the sources and outlining the boundaries of the research problem while pointing out perspectives of new directions of research. The collected data have been analysed resulting in answers to the research question asked.

The following research questions have been formulated for the research work:

1) What has the case law of the European Court of Human Rights been to date related to monitoring employees' Internet use in the workplace?

2) What have the factual and legal bases been for the ECHR adjudicating in Case of Bărbulescu v. Romania?

3) How has the monitoring of employees' Internet use in the workplace been formulated in national legislation and selected case law of Polish courts?

\section{Scope of the protection of the right to privacy in the European Convention on Human Rights: selected theoretical considerations}

The European Court of Human Rights is a body of international justice, competent to adjudicate cases related to complaints against breaches of rights specified in the 
Convention for the Protection of Human Rights and Fundamental Freedoms (hereinafter Convention) and its additional Protocols. The signing of the Convention was motivated by the need to establish human rights protection standards in post-war reality, which included the right to privacy ${ }^{1}$.

Its reflection can be found in Article 8(1) of the Convention, pointing out to the scope of the legally protected goods, together with a list of values, covering private life, family life, home and correspondence ${ }^{2}$. The absence of an unambiguous terminological scope of the 'private life' category, thus the removal of the normative definitions of the individual terms making it up, suggests a need for analysis of the case law of the ECHR, as well as courts in individual countries (Czubik 2013).

The main approach presented by the ECHR concerning the protection of the right to respect for private life indicates obliging the state in terms of protecting the individual against breaches stemming from abuses by public authorities. Consequently, the state should refrain from unjustified breaches pursuant to Article 8(2) of the Convention³. The other concept is based on a positive obligation covering both protection of the individual by the state and imposing obligations on the state aimed at making it take actions to protect the right to private life, family life, home and correspondence 4 .

From the perspective of theoretical considerations regarding the monitoring of the employee's Internet use in the workplace discussed here, the absence of normative definitions of terms and direct references to the phenomenon forces us to perform an indepth analysis of the relevant case law of the European Court of Human Rights. However, any legal analysis should begin from the notion of human rights, then narrowing the research area down to the European context, the content of the Convention, the right to privacy in the meaning of Article 8 of the Convention, and then the right to the protection of correspondence, understood as one of the forms of interpersonal communication.

The original justification of applying Article 8 of the Convention to correspondence pertained to postal services, aspects of correspondence in prisons, or wiretapping and conversation recording 5 . It was only later judgments of the ECHR that allowed for further

1 The Convention was signed in Rome on 4 November 1950 and entered into force on 8 September 1953. At present, 47 European countries are parties of the Convention. Poland joined the Convention on 19 January 1993, and since 1 May 1993 Poland has been recognising the jurisdiction of the European Court of Human Rights to receive complaints of individuals.

2 The Article 8 of the Convention: "1. Everyone has the right to respect for his private and family life, his home and his correspondence. 2. There shall be no interference by a public authority with the exercise of this right except such as is in accordance with the law and is necessary in a democratic society in the interests of national security, public safety or the economic well-being of the country, for the prevention of disorder or crime, for the protection of health or morals, or for the protection of the rights and freedoms of others."

3 This current interpretation regarding the right to private life is the dominant one in the European Court of Human Rights. Its philosophical origins can be traced back to concepts proposed by J.Locke and J.J.Rousseau, which are in essence a liberal approach to human rights understood as a freedom zone of the individual limited solely in circumstances that are extraordinary and justified (by law).

4 The other current interpretation regarding the right to private life is based on the notion of the welfare state.

5 See: Case of X. v. Germany, 1979, no. 8383/78 (3 October 1979); Case of Campbell v. the United Kingdom, 1992, no. 13590/88 (25 March 1992) A 233; Case of Huvig v. France, 1990, no. 11105/84 (24 April 1990) A176-B. 
interpretative suggestions as regard the notion of correspondence in employee relations, with a breakthrough ECHR judgment of 1997 in Case of Halford v. the United Kingdom (ECHR 20605/92), where the Court found that telephone calls from the workplace could fit within the term "private life and correspondence", being covered by the notion of a "reasonable expectation of privacy". That, in turn, became the basis for applying Article 8 of the Convention also to the possible monitoring of internet use in the workplace in circumstances justified by law (see the 2007 ECHR judgment in Case of Copland v. the United Kingdom and the 2017 ECHR judgment in Case of Bărbulescu v. Romania).

Recognising the need of the citizens of the member states of the Council of Europe that have ratified of the Convention for the Protection of Human Rights and Fundamental Freedoms to have a more in-depth understanding of the matter, the author has decided to carry out a detailed analysis of the most recent judgment of the ECHR related to monitoring at work, including the reasons given for judgments of particular instances as well as the final resolution of the case by the Court. European countries, including Council of Europe members, should seek to ensure consistent jurisprudence in the field of possible interference in their citizens' privacy and the aforementioned case marked a breakthrough in the understanding of the matter discussed here.

\section{Description of the circumstances resulting in the ECHR judgment of 5 September 2017 in Case of Bărbulescu v. Romania}

From 1 August 2004 until 6 August 2007, Bogdan Bărbulescu (a citizen of Romania) was employed in a private company as a sales engineer. At his employer's request, for the purpose of responding to customers' enquiries, Bărbulescu created a company's instant messaging account using Yahoo Messenger (ECHR 2017: par.11; Yurkina 2017). The employer's internal regulations, whose copy the Applicant had signed on 20 December 2006 after acquainting himself with their content, prohibited personal use of computers, photocopiers, telephones or fax machines for privat purposes on company premises (ECHR 2017: par.12). An identical information notice was repeated in July 2007 , and Bărbulescu had also acquainted himself with its contents on an unspecified date between 3 and 13 July 2007 (ECHR 2017: par.15, 16). The regulations did not contain any reference to the possibility for the employer to monitor employees' communication (ECHR 2017: par.13).

On 13 July 2007, Bărbulescu was informed that his Yahoo Messenger communication had been monitored by the employer between 5 July and 13 July 2007 and that some evidence of abuse had been found, for instance his Internet activity was more intensive than that of his colleagues (Dijkstra 2017). Bărbulescu replied in writing refuting the charges, as a result of which the employer presented a 45-page transcript of his correspondence unambiguously showing that he indeed had exchanged messages of a private nature with his brother and his fiancée at work (ECHR 2017: par. 21). On 1 August 2007, Bărbulescu was dismissed on disciplinary ground for having breached the company's internal regulations prohibiting use of its resources for private purposes (ECHR 2017: par. 23). 
Bărbulescu appealed to a Country Court, making a case for, inter alia, breaching the constitutional right to secrecy of correspondence (Dale 2016: p. 8). On 7 December 2007. his application was rejected with a justification that his disciplinary dismissal had been lawful and the employees had been informed about the ban on Internet use at work for private proposes (Macfarlane 2016). The Country Court indicated that the monitoring itself had been the only way to check the duties performed and to confirm any possible breaches (ECHR 2017: par. 28).

In his appeal, Bărbulescu raised the fact that email correspondence was subject of protection pursuant to by Article 8 of the Convention, as well as pointed out to some procedural errors made by the first-instance court, which, inter alia, had not allowed any witness hearing since allegedly there had been no evidence of any damage to the employer resulting from his activity (ECHR 2017: par. 22). The applicant also argued that the first-instance court had not struck a fair balance between the interests at stake (Vanesson 2016: p.10). The Appellate Court dismissed the applicant's appeal in its judgment of 17 June 2008, concluding that the employer had behaved reasonably, the monitoring of communication was the only way to find whether the applicant had breached the regulations, and the evidentiary proceedings had been sufficient (ECHR 2017: par. 30).

Bărbulescu appealed to the European Court of Human Rights invoking breaches of his right to private life and correspondence protection (Article 8 of the Convention), while also indicating the absence of a fair trial (Article 6(1) of the Convention) 6 .

On 12 January 2016, a Chamber (Section IV) of the European Court of Human Rights held in its judgement, by six votes to one, that there had been no violation of Article 8 of the Convention regarding the protection of the right to privacy and family life, while the monitoring measures used by the employer had been of proportional nature and justified $^{7}$. The judges of the Court emphasised that phone calls and electronic mail initiated from workplace in principle fitted within the term 'private life' subject to legal protection, while employees could expect that they were not controlled in the workplace, unless they had been informed about such possibility in advance (ECHR 2016: par. 37). The Court did not refer in detail to the notions of transparency or adequacy of the sanction applied with relation to the applicant's breach (Wragg 2016: p.1-2).

The applicant referred the case to the Grand Chamber of the ECHR for renewed consideration ${ }^{8}$.

6 See paragraphs 64-66 of the ECHR judgement of 12 January 2016 in Case of Bărbulescu v. Romania, Application no. 61496/08 (hereinafter ECHR 2016).

7 In the judgment of the Chamber (Section IV) of the European Court of Human Rights of 12 January 2016. it was emphasised that the contract and regulations in the workplace indicated a prohibition of using company devices for private purposes, hence Bărbulescu should have been aware of the existence of a ban on private email correspondence from a company computer. The Court found that monitoring of the employee's correspondence, limited to eight days, was a justified form of checking the quality of the employee's work and his meeting the obligations spelt out in the contractual commitments binding him, as well as that it had been carried out with the conviction that the correspondence pertained exclusively to professional matters.

8 The extensive partly dissenting opinion expressed by Judge Pinto de Albuquerque emphasises the need to establish specific rules regarding monitoring of employees' electronic communications and lack of approval for the blanket rule of banning Internet use for private purposes in the workplace (see 


\section{Judgment of the Grand Chamber of the ECHR of 5 September 2017 in Case of Bărbulescu v. Romania}

In its judgment of 5 September 2017, the Grand Chamber of the ECHR re-assessed the case, pointing out to some failures in the domestic courts' meeting of positive obligations in terms of ensuring the effective exercise of the right guaranteed by Article 8 of the Convention, underlining the need to conduct a thorough analysis of striking a balance between the right to respect for the employee's private life and the employer's interests ensuring the operation of the enterprise (ECHR 2017: par. 112, 127, 139, 141).

The Court emphasised that the term 'private life' did not allow for an unambiguous definition, because it contained both the "inner circle" and the right to lead a "private social life" covering the sphere of the individual's activity at work and elsewhere (ECHR 2017: par.70). Limitations of one's professional life could be protected by the Article 8 of the Convention, if they had no bearing on his/her building a social identity and relations with the outside world (ECHR 2017: par.71).

As the Court underlined, the applicant had been informed about the ban of Internet use for private purposes, but he had not been informed in advance about the scope and nature of the monitoring carried out by the employer or the possibility of the latter's access to his communications (Cabeza Pereiro et al. 2017). As no employer may limit one's private life entirely, the communications performed by Bărbulescu in the workplace were covered by the notions of 'private life' and 'correspondence', thus protected as provided for in Article 8 of the Convention (Boehm et al. 2016).

In the Grand Chamber judgment, the judges referred to the transparency and adequacy of the employer's action concluding that Bărbulescu had not been properly informed by the employer about the monitoring of electronic communications in the workplace and possible consequences of breaches of prohibitions specified in the company's internal policy (ECHR 2017: par.138). The Court's judgment was an obvious indication that the application of the form of control in question had to follow clearly defined rules and be unambiguously presented to the employee as binding principles of the enterprise's policy (ECHR 2017: par.133).

The Grand Chamber judgment invokes Directive 95/46/EC of the European Parliament and of the Council of the European Union of 24 October 1995 on the protection of individuals with regard to the processing of personal data and on the free movement of such data, previously invoked in the judgment of the Romanian Appellate Court, pointing out that the information concerning the monitoring could have been treated as preannouncing it only prior to the actual implementation of the control measure, but not after it (ECHR 2017: par.131). The judges of the Court's Great Chamber emphasised that the applicant had not received information that his employer could access the contents

paragraphs 10-13 of the opinion of Judge Pinto de Albuquerque, EICHR 2016). The judge underlined the aspect of assessing internet access as a human right and questioned the binding nature of the prior notification of the applicant of possible monitoring of his computer (see paragraphs 3 and 18 of the partly dissenting opinion of Judge Pinto de Albuquerque, ECHR 2016). 
of his electronic communication, while the monitoring of the flow and contents of correspondence, as a major intrusion into the right to privacy, required suitable justification and had to be clearly defined?.

It was stressed in the Grand Chamber judgment that although the Romanian courts had taken into consideration the scope of privacy protection and the assessment of the reliability of the disciplinary proceedings, but they had not emphasised the examining the extent in which Bărbulescu had been forewarned of the potentiality and scope of the application of measures limiting his privacy in terms of correspondence in the workplace (ECHR 2017: par.130). The applicant had been informed that his employer did not agree that the company account (or any devices being the company's resources) be used for private purposes, but he had no knowledge about possible control nor had been informed about the intention to carry out a monitoring operation or about a possibility of access to private correspondence, which, according to the Court, did constitute an intrusion into the right to privacy, thus a breach of Article 8 of the Convention. Invoking European standards, the Court pointed out to the need to inform the employee in advance about the intention to monitor electronic correspondence, which includes both specifying the control measure and the scope of its impact (Gray, Henderson 2017).

The national courts did not assess whether the monitoring itself was necessary, apart from a general conclusion that unlawful Internet activity should be prevented. They did not examine whether the performance of the monitoring was justified; consequently, the employer's argument that the company had been put at risk was not substantiated (ECHR 2017: par.145). Moreover, the national courts did not examine whether the objective of the correspondence monitoring could not have been attained using less invasive methods and whether the sanction applied in the case of Bărbulescu, i.e. disciplinary dismissal, had been adequate to the breach level (ECHR 2017: par. 131, 133. 137, 138, 146).

The Court focused on the assessment of the level of restrictiveness of the employer's regulations, which led to the applicant's justified expectation that his privacy be protected, assuming that they might excessively interfere in the individual's social life $^{10}$. The right to protection of privacy and correspondence was subject to limitations also in the professional environment yet it did not disappear altogether, from which

9 In the Grand Chamber judgement, it is indicated that the term "correspondence" was wide-ranging and included both contact by telephone and electronic means (e-mail communication). See: ECHR 2017: par. 25, 54 and 72 .

10 In its judgment of 16 December 1992 in Case of Niemietz v. Germany (no. 13710/88), the Court noted that an activity related to one's profession or conducting business might be carried out in a private residence, by virtue of which, to the contrary, an activity not related to that might be carried out in an office or on commercial premises, hence the interpretation of the term "home" also includes the premises used for economic or professional activity of the individual. The interpretation of the terms "private life" and "home" with reference to the activity carried out and the premises used is consistent with the purpose of Article 8 of the Convention and allows for the assumption that it is possible to attend to private matters from the office and emphasises the blurring of the private and professional spheres. Furthermore, as separating them is becoming ever more difficult, employees' professional activity is subject to the protection provided for in Article 8 of the Convention. 
a positive obligation could be derived on the part of the state being a party to the Convention of ensuring privacy protection by striking a balance between the interests of the employer and the employee (ECHR 2017: par. 112, 127, 139). The interests requiring protection should be reflected in labour law but equally civil and penal law. Such states should be free to create a legal framework of employers' internal regulations in the scope discussed here, yet such freedom may not be unrestricted. According to the Grand Chamber judgment, the states should ensure respect of the rights and interests of the parties adhering to the proportionality principle, which was expressed in a number of the Court's suggestions regarding the consideration of the following factors (ECHR 2017: par.121):

- whether the employee has been notified of the possibility that the employer might take measures to monitor correspondence and other communications, and of the implementation of such measures (the Court emphasised that for the rights spelt out in Article 8 of the Convention to be respected, the employer should be required to make sure the notification is clear about the nature of the monitoring and given in advance);

- the extent of the monitoring by the employer and the degree of intrusion into the employee's privacy (in this regard, a distinction should be made between monitoring of the flow of communications and of their content ${ }^{11}$ );

- the need to justify monitoring of communications and accessing their actual content;

- assessing whether the aim pursued by the employer by means of the employee's monitoring could have been achieved without directly accessing the full contents of his communications, thus whether in a given case less intrusive monitoring measures could have been used,

- examining the consequences of the monitoring for the employee and the use made by the employer of the results of the monitoring operation,

- showing the safeguards applied during the monitoring operation.

The judgment of the Court's Grand Chamber (ECHR 2017) was delivered by eleven votes to six, and repealed the judgment of the ECHR Chamber of 12 January 2016, in which Bărbulescu's application had been rejected. The voting result demonstrated the fact, that the legal qualification of the case can vary ${ }^{12}$.

\section{Assessment of the possibility of monitoring the employees' Internet use in the workplace in the light of selected case law of the European Court of Human Rights}

The European Court of Human Rights performed a two-track analysis of the scope of the monitoring of the employee's internet use in the workplace discussed here.

11 The Court emphasised that assessment should be made in each individual case of the level of correspondence monitoring, its duration and the number of persons with access to its results.

12 The judges, who did not share that conclusion, raised, inter alia, the failure to correctly apply the concept of positive obligations, pointing out to the positive assessment in judgments of the national courts related to striking a balance between the interests of the employee and the employer. 
On the one hand, its case law regards monitoring the employee's email accounts in order to verify the quality of their work as lawful ${ }^{13}$. Collecting such data as the sender's address or even content may be a tool of revealing abuse on the part of the employee ${ }^{14}$.

On the other hand, the Court has emphasised in numerous occasions the need of protecting the employee's rights, differentiating between traffic and content data which have different consequences in the sphere of employee privacy breaches ${ }^{15}$. In their judgments, the judges of the Court have pointed out the need to differentiate between cases when there exists a prohibition of using electronic communications in the workplace and those where such prohibition is not in place ${ }^{16}$. Pursuant to Article 2(b) of Directive 2002/58/EC of the European Parliament and of the Council of 12 July 2002 concerning the processing of personal data and the protection of privacy in the electronic communications sector (Directive on privacy and electronic communications), as traffic data cover, for instance, the sender's (or the recipient's) address, and so provide information about the employee, a view can be found in the Court's case law that monitoring them is lawful, as a result of the assumption that using a company's email account for private purposes is in breach of the contract concluded between the employer and the employee. ${ }^{17}$ As regards monitoring of the contents of electronic mail, the level of the employer's intrusion is much higher, as emphasised by the Court in its judgments pointing out to the unlawfulness of such operations, unless the employer has introduced in the workplace rules for limiting the scope of such activities of the employee in the contract or its internal policy (workplace regulations).

${ }_{13}$ In the ECHR of 25 August 1997 in Case Halford v. the United Kingdom (no. 20605/92) concerning an individual's right to an effective measure of protection against unlawful breaches of the right to privacy, the Court broadened the definition of the term "private life" by including telephone calls made from company devices. The employee retained the right to privacy also while performing professional duties, with the proviso that in specific circumstances that right could be restricted, inter alia, for the purpose of monitoring the quality of the performance of one's duties and ensuring a correct course of employees' work. Given that argumentation, the employee has a reasonable expectation concerning privacy when making telephone calls using the employer's devices, and consequently telephone calls made from company premises and from home can be considered a sphere of 'private life' and 'correspondence' in the meaning of Article 8 of the Convention, as confirmed by the judgment of the Court in Case of Klass and Others v. Germany of 6 September 1978 (no. 5029/71) as well as the Court's judgment in Case of Malone of 2 August 1984 (no. 8691/79). As a result, monitoring of such calls does constitute a breach of Article 8 of the Convention (Case of Halford v. the United Kingdom, paragraph 50). In Cases of Copland v. the United Kingdom (2007. ECHR 62617/00) and Malone v. the United Kingdom (1984, ECHR 8691/79), the Court found that the earlier interpretation also included telephone calls, electronic mail and metadata constituting an integral part of the communication. Thereby, the Court confirmed that Article 8 of the Convention covered positive obligations made between employees and the employer in the area of the private sphere.

14 Case of Halford v. the United Kingdom, 1997, ECHR 20605/92, paragraph 48.

15 Case of Malone v. the United Kingdom, 1984, ECHR 8691/79, paragraph 84. Case of Copland v. the United Kingdom, 2007, ECHR 62617/00, paragraph 43.

16 Case of Halford v. the United Kingdom, 1997, ECHR 20605/92, paragraph 45. Case of Copland v. the United Kingdom 2007, ECHR 62617/00, paragraph 42.

17 Art. 2 (b) of Directive 2002/58/EC: 'traffic data' means any data processed for the purpose of the conveyance of a communication on an electronic communications network or for the billing thereof. See the Court judgement of 12 January 2016 (Case of Bărbulescu v. Romania), paragraph 57. 


\section{Employees' internet use in the workplace in the light of Polish legislation and selected case law}

In terms of assessing the protection of the right to privacy and of correspondence confidentiality from the employee's viewpoint, Polish case law is relatively scarce. The Supreme Court has ruled a number of times assessing the circumstances of employees' use of company computers for private purposes, but from the standpoint of the extent of damage to the employer's interest of a property or non-property nature ${ }^{18}$.

In the context of domestic legislation, the field of breaching employee obligations has been expressed in Article 52(1)(1) of the Labour Code, which constitutes a basis for an employee's disciplinary dismissal without notice ${ }^{19}$. By contracting an employment relation, the employee automatically undertakes to perform a specific kind of work for the employer, which entails the requirement of its conscientious and diligent performance laid down in Article 100(1) of the LC. ${ }^{20}$

The Article 100(2) of the LC contains some examples of the employee's obligations like respecting working time and work regulations, as well as the order set in the workplace, caring about the interest of the workplace, protection of its good name and keeping confidential information, the disclosure of which could put the employer at the risk of a loss or damage, keeping secrets defined in separate provisions of law, as well as respect for the principles of community life.

In the context of the notion discussed here, i.e. use of the employer's devices and resources made available to the employee in the workplace for private purposes, of key importance becomes the aforementioned aspect related to the conscientious and diligent performance of work, understood as using the entire specified working time for professional activity. In the doctrine, cited as examples of such breaches are the already mentioned use of the mailbox for private purposes, which does not equal, however, the employee's serious breach of the basic employee obligations specified in Article 100(1) in conjunction with Article 52(1)(1) of the LC ${ }^{21}$. The rights and obligations of the employer and the employee are defined in the work regulations and the working order established in the workplace, pursuant to Article 104(1) of the LC. That internal act regulating the rights and obligations of the parties to a given employment relation also includes matters of organisational rules or other instructions issued by the employer (Muszalski 2017).

25 May 2016 saw the entry into force of Regulation (EU) 2016/67922 of the European Parliament and of the Council of 27 April 2016 on the protection of natural persons with

18 Supreme Court judgment of 4 November 2010 (II PK 110/10). Supreme Court judgment of 6 July 2011 (II PK 13/11).

19 Labour Code Act of 26 June 1974 (Journal of Laws 1974 no. 24 item 141, as amended), hereinafter the 'LC'.

20 The cited conscientiousness is the employee's attitude to the work performed, which, however, is a subjective matter as one depending on the work performed, its nature and the post held.

21 See Supreme Court judgment of 17 May 2013 (II PK 263/12, Legalis). In the case law of the Supreme Court, there are judgments suggesting that using company equipment without the employer's knowledge could be considered as the basis for employment contract termination without notice (See Supreme Court judgment of 24 February 1998 I PKN 547/97).

22 General Data Protection Regulation (OJ L of 2018 no. 127/2), hereinafter the GDPR. 
regard to the processing of personal data and on the free movement of such data, and repealing Directive 95/46/EC, amending the provisions of hundreds of Polish domestic legal acts, including the LC. Its amendment introduced new regulations that unambiguously defined the notion in question. Pursuant to Article $22^{3}(4)$ of the LC, the employer may control the use of the employees' company computers, as well as keep a detailed record of internet activity, when that is necessary to ensure work organisation enabling a full use of the working time and correct utilisation of the working tools made available to the employee (Article $22^{3}(4)$ of the LC). The said monitoring may not, however, breach the privacy of correspondence or other personal rights of the employee. Importantly, for the introduction of company computer monitoring no employee consent is needed, while its scope is defined in the work regulations, a collective work agreement or a public notice, pursuant to Article $22^{3}(4)$ in conjunction with Article $22^{2}(6)$ of the LC.23 Such provisions must comply with the principles of legality, reliability and transparency as well as objective limitation, data minimisation, correctness, data storage restriction, integrality and confidentiality as well as accountability, pursuant to Article 5 in conjunction with recitals 39-47, 58 and 60 of the GDPR. The employer is obliged to notify the employees of the fact that monitoring has been introduced not later than two weeks prior to its activation, pursuant to Article $22^{3}(4)$ in conjunction with Article $22^{2}(7)$ of the LC in a manner of his own choosing (Article 12(1) of the GDPR) ${ }^{24}$. Before allowing them to commence work, the employer should provide new employees with written information concerning the objective, scope and method of the monitoring, confirmed by an attestation, as well as mark the devices (computers) subject to such monitoring in a visible and clear manner, by means of appropriate signs or sound aspects, not later than a day prior to the monitoring activation.

Polish case law concerning the employee's use of company equipment for private purposes may be scarce, yet in the rulings delivered thus far one could discern an ever present position stressing the need to ensure a margin of acceptance for the existence of the employee's private sphere of activity in the workplace.

In the judgment of the Polish Supreme Court of 22 March 2016 we can read that "not always may the employee be deprived of the possibility to incidentally use certain company equipment (e.g. a telephone or a computer) in order to meet his vital needs for private purposes, if such actions do not render harm to the employer or undermine the essence of the employment relation as well as do not breach company rules or general principles of community life (Article 100(2)(6) of the LC)."25

23 Pursuant to Article $104^{2}(1)$ and Article $241^{9}(1)$ of the LC, the employer must agree the provisions in collective agreements and work regulations with the company trade union. Should no agreement be found within a specified deadline, or in case of the absence of such company union, the employer may decide on their own as regards the work regulations yet not the collective agreement. However, the employer is entirely free in the case of notices.

24 A possible breach of provisions on monitoring contained in work regulations, i.e. failure to make the required agreement with the company trade union will lead to such regulations being null and void (Supreme Court judgment of 21 March 2001, file ref. I PKN 320/00, OSNP 2002/24/599).

25 Supreme Court judgment - Chamber of Labour, Social Insurance and Public Affairs of 22 March 2016 (II PK 31/15). 
Each and every time, the damage/loss potentially suffered by the employer as a result of the employee's use on internet connection necessary for email (and internet communicators) communications needs to be assessed individually, which entails damage liability on his part, not subject to exclusion pursuant to Article 117(2) of the LC (limits of admissible risk). Any possible liability release would be possible when proving that the damage/loss has been incurred as a result of hardware use for company purposes.

In its judgment of 4 April 2017, the Supreme Court referred to the employee's use of company hardware for private purposes, emphasising the major impact of the internet (and internet communications) in the present reality ${ }^{26}$. In the summary of the ruling, we can read that: "the obligation to refrain from performing private work at workplace using equipment and materials without the employer's explicit consent could be treated as elementary. On the other hand, the stage of law implementation should account for cases when the employee's behaviour deviating from the aforementioned standard is accepted. Meant are cases when "while remaining at the disposal of the employer" the employee uses company equipment (a computer, a telephone, a tablet, etc.) in order to send/receive electronic or verbal messages. Hence, sending occasional greetings as well reading electronic results of laboratory tests or an electronic school register of a child ties up with a sequence of interpersonal contacts by means of social media. The development of such means of communication imposes a rapid decoding of the employees' behaviour in the course of the work provision process. The means of communication in question is instantaneous and statistically does not cease to relate to performing work. In each case, however, there exists a limit to such contacts, because the so-called soft interpretation may be a temptation to allow the multiplication of such behaviour as admissible. Consequently, the oftentimes correct conclusion will be a derivative of specific behaviours, the number of events or the time devoted to duties other than professional".27

Given the relatively scarce domestic case law in the scope discussed here, the more pertinent becomes the interpretive context of the ECHR Grand Chamber judgment of 5 September 2017 in the Case of Bărbulescu v. Romania (see: Eichenhofer 2016).

\section{Conclusions}

The ECHR judgments may not make law, but they can influence interpretation of regulations as well as contribute to more transparency of interpretation of legislation in the

26 Supreme Court judgment - Chamber of Labour, Social Insurance and Public Affairs of 4 April 2017 (II PK 27/16).

27 Using company equipment (such as computers) for purposes not related to work entails a number of legal consequences, e.g. in the field of intellectual property rights. It is the work performed in compliance with the scope laid down in the agreement binding the employee and the employer that sets the framework for the author's economic rights of the latter. However, the circumstances are different when the very same employee performs when at work tasks that do not feature in the said agreement. Of essence here is the contents of the agreement binding the employee and the employer rather than the ownership of the equipment used for given work. In the context of using employee monitoring, the employer should also take into account personal data protection legislation, as the Supreme Administrative Court pointed out in its judgment of 13 February 2014 (I OSK 2436/12). 
sphere of, inter alia, privacy and data protection in the 47 countries that are members of the Council of Europe as a specific set of requirements related to monitoring employees' internet use. In the discussed here judgment of the Court's Grand Chamber of 5 September 2017 in the Case of Bărbulescu v. Romania marking the first time, that the circumstances of monitoring an employee's electronic communications by a private employer had been assessed, the Court made a precise list of criteria to be used by national authorities when evaluating whether a given measure serving to monitor them was proportional given the aim intended, and whether the employee was protected against arbitrary judgments ${ }^{28}$.

Summing up the substantive contents of the widely commented judgment of the Grand Chamber, one needs to stress that the employer can control and monitor the employee's electronic communication channels used for professional purposes as well as to demand of the employee not to use them for private purposes, subject to prior explicit notification of the fact, including the indication of its scope and method ${ }^{29}$. Otherwise (in the absence of such information), the right to respect for the employee's private life and correspondence may be breached, thus breaching Article 8 of the Convention. The judgment contains no general prohibition of such activity on the part of the employer yet it speaks of the need to precisely justify individual provisions restricting the sphere in question within a necessary framework. From the employee's point of view, it is essential that the Court's judgment imposes the transparency of any possible techniques and forms of control applied by employers.

It is important to underline the chronology of the events, i.e. the direction of the interpretation of legislation on the right to privacy in the European context, ECHR case law and the legislative changes after the GDPR regulation came into force on 24 May 2016. It is only a combination of all these elements that makes it possible to clearly specify the boundaries of applying monitoring of employees in the workplace.

Karolina Mania - PhD, barrister. She works at the Chair of Strategic Management in the Institute of Economy, Finance and Management (Faculty of Management and Social Communication, Jagiellonian University).

E-mail: karolina.mania@uj.edu.pl

Karolina Mania - doktor, adwokat. Pracuje w Katedrze Zarządzania Strategicznego w Instytucie Ekonomii, Finansów i Zarządzania (Wydział Zarządzania i Komunikacji Społecznej, Uniwersytet Jagielloński).

Adres e-mail: karolina.mania@uj.edu.pl

28 In the context of the subject matter discussed here, it is worthwhile to mention the pending case of Libert v. France (no. 588/13). The application was sent to the French Government on 30 March 2015. In it, one of the applicant's accusations is breaching his right to respect for private life given that his employer (the French railway company SNCF) opened files named 'D: / personal data' on the hard disc of a company PC during his absence and then dismissed him. See https://hudoc.echr.coe.int/ eng\#[ „itemid":[„001-154050"]\} [accessed on 30 October 2017].

29 The Court did not order any indemnity concluding that a breach of the Convention should be sufficient given the moral damage sustained. Still, Romania is obliged to reimburse the applicant for the costs and expenses incurred. 
76 Karolina Mania

\section{$\Theta$ References}

BOEHM F., HEY T., ORTNER R. (2016), How to measure IT security awareness of employees: a comparison to e-mail surveillance at the workplace, "European Journal of Law and Technology", vol. 7. no 1, p. 1-15.

CABEZA PEREIRO Jaime et al. (2017), Is the employer entitled to survey employee's internet communications in the workplace? Case of Barbalescu v. Romania, in: F. Campos Freire, X. Rúas-Araújo, V.A. Martínez-Fernández, X. López-Garcia (eds), "Media and Metamedia Management", Springer, p. 87-93.

CONVENTION for the Protection of Human Rights and Fundamental Freedoms (Rome, 4 November 1950) (Journal of Laws 1993 no. 61 item 284, as amended).

CZUBIK A. (2013), Prawo do prywatności. Wptyw amerykańskich koncepcji i rozwiazań prawnych na prawo międzynarodowe, Instytut Multimedialny, Kraków, p. 288-359.

DALE J. (2016), Monitoring employees' emails, "Timber Trades Journal", Tonbridge 6791, March 2016.

DIJKSTRA S. (2017), The Freedom of the Judge to Express his Personal Opinions and Convictions under the ECHR, "Utrecht Law Review", Volume 13, Issue 1, p. 1-17.

DIRECTIVE 95/46/EC of the European Parliament and of the Council of the European Union of 24 October 1995 on the protection of individuals with regard to the processing of personal data and on the free movement of such data (OJ $L 281,23.11 .1995$, p. 31-50).

DIRECTIVE 2002/58/EC of the European Parliament and of the Council of 12 July 2002 concerning the processing of personal data and the protection of privacy in the electronic communications sector (Directive on privacy and electronic communications), OJ L 201, 31.7.2002, p. 37-47

ECHR (2016), Judgement of the ECHR of 12 January 2016 in Case of Bărbulescu v. Romania, Application no. 61496/08

ECHR (2017), Judgment of the ECHR of 5 September 2017 in Case of Bărbulescu v. Romania, Application no. 61496/08.

EICHENHOFER J. (2016), Internet Privacy at Work - the ECtHR Bărbulescu Judgment, "European Data Protection Law Review", 2/2016, p. 266-271.

GRAY D., HENDERSON S. (eds.) (2017), European Human Rights, Criminal Surveillance, and Intelligence Surveillance: Towards ,Good Enough' Oversight, Preferably But Not Necessarily by Judges, "Cambridge Handbook of Surveillance Law", 2017, p. 8-11.

MACFARLANE A. (2016), When using surveillance to monitor an employee's internet usage in the workplace, has the employer's interference of an employee's Article 8 right to respect for private life and correspondence become so unfettered that the legitimacy of it is disregarded? in: SLSA Annual Conference, 5-7 April 2016, Lancaster.

REGULATION (EU) 2016/679 of the European Parliament and of the Council of 27 April 2016 on the protection of natural persons with regard to the processing of personal data and on the free movement of such data, and repealing Directive 95/46/EC (General Data Protection Regulation), OJ L of 2018, no. 127/2.

VANESSON E. (2016), Legal opinion... UK emlpoyers do not have the green light to spy on employees, "Employers' Law", March 2016.

WRAGG P. (2016), No employer right to snoop but what of employee rights at work?, "Communications Law", vol. 21, no. 1. 
YURKINA E. (2017), Surveillance in the workplace: States' positive obligations in the case-law of the European Court of Human Rights, "Note e commenti", 2017/3, ISSN: 2037-6677, p.773-779.

Acts of Polish national law:

Labour Code Act of 26 June 1974 (OJ 1974 no. 24 item 141, as amended).

Muszalski W. (ed.) (2017), Kodeks pracy. Komentarz, Warsaw

European Case law:

Case of Malone v. the United Kingdom, 1984, ECHR 8691/79.

Case of Halford v. the United Kingdom, 1997, ECHR 20605/92.

Case of Copland v. the United Kingdom, 2007, ECHR 62617/00.

Case of X. v. Germany, 1979, no. 8383/78 (3 October 1979).

Case of Campbell v. the United Kingdom, 1992, no. 13590/88 (25 March 1992) A 233.

Case of Huvig v. France, 1990, no. 11105/84 (24 April 1990) A176-B.

Polish case law:

Judgment of the (Polish) Supreme Court of 4 November 2010 (II PK 110/10).

Judgment of the (Polish) Supreme Court of 6 July 2011 (II PK 13/11).

Judgment of the (Polish) Supreme Court - Chamber of Labour, Social Insurance and Public Affairs of 22 March 2016 (II PK 31/15).

Judgment of the (Polish) Supreme Court - Chamber of Labour, Social Insurance and Public Affairs of 4 April 2017 (II PK 27/16). 